
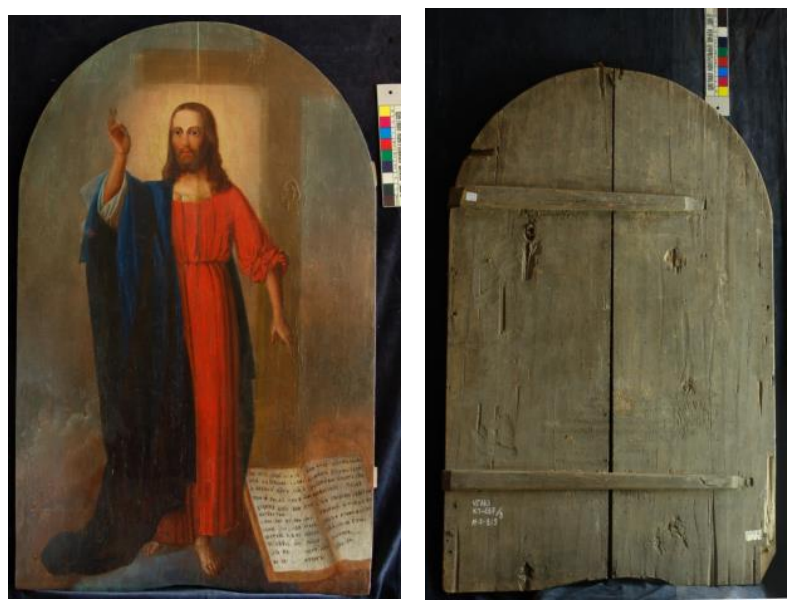

Література:

1. Алешин А.Б. Реставрация станковой масляной живописи: уч. пос. М.: Художественная школа, 2013. - 224 с., ил.

2. Горин И. П., Черкасова 3. В. Реставрация произведений станковой масляной живописи. - М.: Искусство, 1977. - 223 с.

3. Никитин М. К., Мельникова Е. П. Химия в реставрации: Справ. изд. - Л.: Химия, 1990. - 304 с.

4. Сланський Б. Техніка живопису та рест аврації. - К., 2009. - 304 с., іл.

DOI https://doi.org/10.30525/978-9934-26-004-9-59

\title{
«ПЕРЕДЧУТТЯ ГОЛГОФИ» МИКОЛИ СТОРОЖЕНКА
}

\author{
Петрук P. I. \\ заслужений діяч мистеитв Украӥни, \\ дочент кафедри монументально-декоративного \\ і сакрального мистеитва
}

Київської державної академї декоративно-прикладного мистецтва і дизайну імені Михайла Бойчука м. Київ, Украӥна

Микола Андрійович Стороженко (1928-2015) - живописець, графік, майстер монументально-декоративного i сакрального мистецтва, 
академік НАМ України (2000), народний художник України (1997), професор Національної академії образотворчого мистецтва і архітектури (НАОМА) (1991), лауреат Державної премії України імені Тараса Шевченка (1988), член Національної спілки художників України видатний український педагог і мистець другої пол. XX ст. - поч. XXI ст. Мистець також відомий як засновник і керівник майстерні живопису i храмової культури (1994-2015) в НАОМА.

Мистецький шлях художника розпочався в стінах Одеського державного художнього училища під керівництвом М. Шелюто, який по закінченню училища дав рекомендацію для вступу до Київського державного художнього інституту. Серед педагогів Стороженко виділяв С. Григор'єва, Т. Яблонську. Навчання в таких відомих особистостей, вихованців та продовжувачів школи Ф. Кричевського, котрі мали суттєвий вплив на формування мистецького контексту другої пол. XX ст., - вивело художника на високий фаховий рівень як живописця i рисувальника, майстра станкової картини. Доцільно зауважити, що дослідження Стороженком спадщини М. Бойчука та його учнів, де сповідувалась концепція «колективного я», яка згодом стала одним 3 постулатів майстерні Стороженка, відіграло важливу роль у формуванні ним світоглядних позицій на монументальне мистецтво.

Розписи купола Пресвятої Трійці у храмі Миколи Притиска у Києві (1997-2000), енкаустика Інституту фізики НАН України під назвою «Осяяні світлом» (1977-1980), мозаїка «Україна скіфська - Еллада степова» (1987-1991), графічні цикли ілюстрацій до творів українських письменників (Лесі Українки, М. Коцюбинського, М. Стельмаха, I. Франка); варто відзначити «Українські народні казки», за які мистець отримав Шевченківську премію, - все це стало шляхом до написання «роботи життя» Миколи Стороженка, полотна «Передчуття Голгофи», у якому, за словами самого професора, закодована мораль майбутньої еліти. Численні образи-символи, якими наповнена робота, ніби огорнуті сяйвом, постаті оповиті примарним флером ніжно-пастельних тонів: прозорий живопис, метафізична сутність якого відкрита [3, с. 9-10].

«Передчуття Голгофи» - знакова композиція в історії українського мистецтва часів незалежності. Чи не наймасштабніше полотно, розміром близько 4 на 7 метрів. Початок роботи над твором датований 2001 роком під назвою «Агнець» [1, с. 160]. Картина виконана в авторській техніці на основі водних розчинів (темпера, гуаш, акварель, акрил) 3 авторськими фіксажними сумішами, із збереженням фактури полотна як одного 3 елементів внутрішньої дії твору. Сама назва, як і формат, упродовж роботи змінювались мистцем не раз: «Агнець» - «Чаша» - 
«Таємна вечеря» - «Передчуття Голгофи». Часто сприймають полотно за поліптих, оскільки воно складається з восьми різномодульних елементів. У такий спосіб було вирішено проблему зручності транспортування роботи, ії мобільності.

Прем'єрна презентація твору відбулась у приміщенні Національної академії мистецтв України (2013), де Стороженком здійснено було перформативну акцію - омовення ніг учням перед роботою як знак вивершення головної ідеї картини - подолання «егоїстичного я». Згодом «Передчуття Голгофи» презентували в Івано-Франківську (2015), Львові (2015), Чернігові (2015), що викликало певний суспільний резонанс. З 2015 року полотно експонується в актовій залі НАОМА.

Будучи педагогом і методистом, Микола Стороженко не один рік працював над ескізами до цього твору, які переросли у виконання картону в масштабі 1:1. Збір матеріалу, сотні штудій, варіанти зображення жестів рук, міміки облич, привели мистця до розробки авторського методу компонування - «метафізичного трансмобілу», коли на окремих паперових сегментах промальовувався кожен структурний елемент картини - образ чи складка, що дозволяло рухати їх по площині формату довільно, а вивіривши точне місце зафіксувати, не перемальовуючи по декілька разів.

Принцип трактування композиції - герменевтичний. Відбувається зміщення часових проміжків воєдино, тобто, один герой зображується в різних іпостасях, зокрема Христос. У центральній нижній частині полотна Він омиває ноги своєму учневі, зліва вгорі причащає апостолів (там також бачимо напис «Ця Чаша Новий завіт»), а вгорі справа ділить між ними хліб (там напис «Я хліб життя»). Колірну гаму твору, що побудована на мікронюансах білого 3 елементами абстрагованих декоративних символічних колірних плям-вкраплень червоного та синьозеленого, вивершують лотоси - символи духовної чистоти, що розміщені обабіч духовного дійства. Глибинне смислове навантаження відіграють образи Чаші та Агнця, що вивершують центральну вісь композиції.

Майстер, на противагу законам станкової картини (якою ії розуміли за радянських часів), вивершує твором «Передчуття Голгофи» авторську ідею-поняття - «антикартина». За Стороженком: «Сьогодні (кінець XX i початок XXI ст.) не станкова картина, а «містерія станковості», в якій більше можливостей, де б могли відбуватися гармонія взаємодії стихій (на рівні зримого життя і на рівні онтології Буття)» [2]. Важливим джерелом для наближення до авторської філософії твору «Передчуття Голгофи» $є$ опубліковані власні роздуми Миколи Стороженка щодо цього твору: «Я не аналізую цей твір, а визначаю тези до мистецтва в 
цілому, що буде відповіддю і на мою творчість, на синтез змісту і форми, без пріоритету одного над другим» [2].

По суті, це тема «Таємної вечері», яку порушували багато мистців, серед яких Стороженко особливо виділяв Леонардо да Вінчі («Таємна вечеря», фреска, 1495-1497) та Сальвадора Далі («Таємна вечеря», 1955) (використання симетрії в побудові композиції якого було суголосним Стороженковій концепції). Проаналізувавши варіації на цю тему зазначимо, що вирішення теми Стороженком $є$ до певної міри новаторським.

Варто зауважити органічність поєднання реальності з метафорами, що складаються у філософські узагальнення і становлять унікальність полотна «Передчуття Голгофи» Миколи Стороженка, що стало концептуалізацією його світорозуміння й світовідчуття, вивершення ірраціонального над раціональним.

\title{
Література:
}

1. В. Войтович. Микола Стороженко. Альбом. К., Дніпро, 2008. 176 с.

2. Микола Стороженко. Передчуття Голгофи. До 85 річниці з дня народження. К., 2013. [Б. в.].

3. Микола Стороженко - художник, педагог, людина: зб. тез доповідей наук.-практ. конф., Київ, 08 листопада 2018 р. - К., 2018. - 37 с.

DOI https://doi.org/10.30525/978-9934-26-004-9-60

\section{ПИТАННЯ КОЛЬОРОУТВОРЕННЯ В КОНТЕКСТІ СУЧАСНИХ ТЕКСТИЛЬНИХ ПРАКТИК}

\author{
Печенюк Т. Г. \\ кандидат мистеитвознавства, доцент, \\ завідувачка кафедри художнього текстилю \\ Львівської національної академї мистецтв \\ м. Львів, Украӥна
}

Колір посідає чи не найголовніші позиції в різних сферах мистецьких та дизайнерських практик, серед яких і практики сучасного художників текстилю. Свого часу саме художня тканина стала об'єктом представлення ідей живописної метафізики початку XX ст., де колір розглядався як матеріалізоване світло. Прикладом чого може бути апробація теоретичних ідей Роберта Делоне у прикладних роботах його 226 